\title{
On the Morphology of Strain-Induced Martensite and the Transformation-Induced Plasticity in $\mathrm{Fe}-\mathrm{Ni}$ and $\mathrm{Fe}-\mathrm{Cr}-\mathrm{Ni}$ Alloys*
}

\author{
By Imao TAMURA, ${ }^{* *}$ Tadashi MAKI, ${ }^{* *}$ and Hiroshi HATO ${ }^{* * *}$
}

\section{Synopsis}

In order to study the morphology of strain-induced martensite and the plasticity induced by the martensitic transformation, tensile tests at various temperatures were carried out using $\mathrm{Fe}-31 \% \mathrm{Ni}, \mathrm{Fe}-29 \% \mathrm{Ni}-0.26 \% \mathrm{C}$ and $\mathrm{Fe}-15 \% \mathrm{Cr}-13 \% \mathrm{Ni}$ alloys whose Ms temperatures were below room temperature and the microstructures were observed. The results obtained are summarized as follows.

In $\mathrm{Fe}-\mathrm{Ni}$ and $\mathrm{Fe}-\mathrm{Ni}-\mathrm{C}$ alloys, a characteristic martensite whose morphology is entirely different from that of thermally transformed martensite is formed by tensile deformation mainly at the temperatures between $\mathrm{Md}$ and Ms. This characteristic martensite is formed contimuously little by little with increasing strain and contributes to the transformation-induced plasticity. The difference of morphology between thermally transformed martensite and strain-induced martensite must be caused by the change of transformation mechanism. In the case of $\mathrm{Fe}-\mathrm{Cr}-\mathrm{Ni}$ alloy, however, the morphology of strain-induced martensite is not different from that of thermally transformed martensite.

Transformation-induced plasticity occurs in $\mathrm{Fe}-\mathrm{Ni}$ alloys and the $\mathrm{Fe}-$ $\mathrm{Cr}-\mathrm{Ni}$ alloy. The elongation has a maximum value at a temperature between Md and Ms. In the test in which the maximum elongation is obtained, the strain-hardening exponent increases continuously with increase in strain. The main prerequisite for maximum elongation is that the martensite is constantly formed little by little during deformation up to fracture. The difference between the $\mathrm{Fe}-\mathrm{Ni}$ alloys and the $\mathrm{Fe}-\mathrm{Cr}-\mathrm{Ni}$ alloy is that the temperature range showing large elongation is wider in the $\mathrm{Fe}-\mathrm{Cr}-\mathrm{Ni}$ alloy than in $\mathrm{Fe}-\mathrm{Ni}$ alloys. This is caused by the difference in transformation behavior of martensite.

\section{Introduction}

It is well known that the martensite is formed from metastable austenite by deformation at temperatures below Md. ${ }^{1-13)}$ The morphology of strain-induced martensite has been investigated in $\mathrm{Fe}-\mathrm{Cr}-\mathrm{Ni}$ alloys ${ }^{\text {7) }}{ }^{12)}$ (mainly stainless steels) and $\mathrm{Fe}-\mathrm{Mn}$ alloys, ${ }^{13)}$ but has never been reported in $\mathrm{Fe}-\mathrm{Ni}$ alloys. It has been also reported that large elongation is produced by the martensitic transformation during the deformation in stainless steels. ${ }^{14), 15)}$ Such a phenomenon is called transformation-induced plasticity. Recently, utilizing this phenomenon, the TRIP steel having excellent combinations of strength and elongation has been developed with attractive prospects. ${ }^{16)-18}$ ) However, the basic investigations on transformation-induced plasticity have been few in number, and especially have not been made except for stainless steels ( $\mathrm{Fe}-\mathrm{Cr}-\mathrm{Ni}$ alloys). Since $\mathrm{Fe}-\mathrm{Ni}$ alloys, as $\mathrm{Fe}-\mathrm{Cr}-\mathrm{Ni}$ alloys, show a typical martensitic transformation, it is expected that transformation-induced plasticity may be observed.

The purpose of this investigation is to study the transformation-induced plasticity and the morphology of strain-induced martensite in $\mathrm{Fe}-\mathrm{Ni}$ alloys whose $\mathrm{Ms}$ temperature is below room temperature, and also to further clarify these phenomena in $\mathrm{Fe}-\mathrm{Cr}-\mathrm{Ni}$ alloy.

\section{Experimental Procedure}

The alloys used in this investigation were prepared by vacuum induction melting and had the compositions shown in Table 1 . In this table, Ms and $\mathrm{Md}$ temperatures are also shown. They were hot-forged to produce a sheet about $10 \mathrm{~mm}$ thick, and then homogenized at $1200^{\circ} \mathrm{C}$ for $20 \mathrm{hr}$ in vacuum. After the homogenization, sheets of $0.5 \mathrm{~mm}$ thick were prepared by cold-rolling. Specimens for tensile tests were machined parallel to the rolling direction of the sheets. The shape of tensile specimens is shown in Fig. 1. Fe$\mathrm{Ni}-\mathrm{C}$ and $\mathrm{Fe}-\mathrm{Cr}-\mathrm{Ni}$ alloys were austenitized at $1150^{\circ} \mathrm{C}$ for $3 \mathrm{hr}$, and $\mathrm{Fe}-\mathrm{Ni}$ alloy was austenitized at $1200^{\circ} \mathrm{C}$ for $4 \mathrm{hr}$ in vacuum. After the austenitization, the $\mathrm{Fe}-\mathrm{Ni}$ alloys were cooled in the furnace and the $\mathrm{Fe}-\mathrm{Cr}-$ $\mathrm{Ni}$ alloy was quenched into oil. The specimens were slightly polished by electrolytic polishing prior to testing. Then, they were tensile tested at various temperatures between $+160^{\circ}$ and $-180^{\circ} \mathrm{C}$ with a strain rate of $5.5 \times 10^{-4} \mathrm{sec}^{-1}$. Microstructures of specimens tensile-tested were observed by means of the optical and transmission electron microscopy.

Table 1. Chemical compositions of specimens

\begin{tabular}{|c|c|c|c|c|c|c|}
\hline & \multicolumn{4}{|c|}{ Composition (wt \%) } & \multirow{2}{*}{$\begin{array}{c}\mathrm{Ms} \\
\left({ }^{\circ} \mathrm{C}\right)\end{array}$} & \multirow{2}{*}{$\begin{array}{l}\mathrm{Md} \\
\left({ }^{\circ} \mathrm{C}\right)\end{array}$} \\
\hline & $\mathrm{Ni}$ & $\mathrm{Cr}$ & G & $\mathrm{Fe}$ & & \\
\hline $\mathrm{Fe}-\mathrm{Ni}-\mathrm{C}$ & 28.68 & - & 0.26 & bal & -35 & $\approx+5$ \\
\hline $\mathrm{Fe}-\mathrm{Ni}$ & 30.8 & - & 0.005 & bal & -57 & $\approx-15$ \\
\hline $\mathrm{Fe}-\mathrm{Cr}-\mathrm{Ni}$ & 12.62 & 15.18 & 0.002 & bal & -58 & $\approx+120$ \\
\hline
\end{tabular}

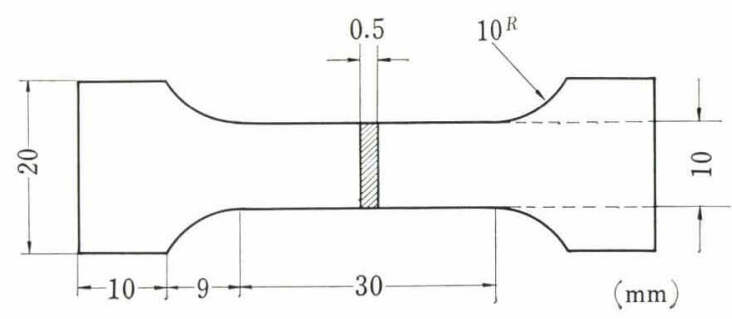

Fig. 1. The shape of the tensile specimen

\section{Experimental Results}

1. The Morphology of Strain-Induced Martensite

(1) Fe-Ni-C Alloy

First the morphology of martensite thermally trans-

* Originally published in J. Japan Inst. Metals, 33 (1969), 1376; 1383 in Japanese. English version received November 5, 1969.

** Department of Metal Science and Technology, Faculty of Engineering, Kyoto University, Sakyo-ku, Kyoto 606.

*** Student of Graduate School, Kyoto University, Sakyo-ku, Kyoto 606. 
formed by subzero-cooling (henceforth, such martensite is called subzero martensite) was observed. Photograph 1 (a) shows the optical micrograph of $\mathrm{Fe}-29 \% \mathrm{Ni}-$ $0.26 \% \mathrm{C}$ alloy subzero-cooled to $-60^{\circ} \mathrm{C}$. This subzero martensite is typical plate-like martensite with a mid-rib, and is formed in bursts. The transmission electron micrograph of this martensite is shown in Photo. 1 (b). The straight dark band in martensite plate is the mid-rib, and transformation twins exist only near the mid-rib. This is called generally the partially twinned martensite. Outside the twinned region is an untwinned region in which high density of dislocations may exist. In such a region, numerous dislocations lying along some directions have been actually observed for partially twinned martensites of $\mathrm{Fe}-\mathrm{Ni}$ alloy. ${ }^{19), 20)}$ In $\mathrm{Fe}-\mathrm{Ni}-\mathrm{C}$ alloy, however, the contrast of dislocations hardly appears in the transmission electron micrograph as shown in Photo. 1 (b). The same phenomenon has also been observed by other workers. ${ }^{21)}$ The reason for this phenomenon is not clear now, though it is considered that carbon atoms may play an important role.

The typical optical micrographs of strain-induced martensite are shown in Photos. 2 (a) and (b). These martensites were formed by tensile deformation $(34 \%$ in tension) at $-11^{\circ} \mathrm{C}$, which was between $\mathrm{Md}$ and $\mathrm{Ms}$. As shown in Photo. 2 (a), strain-induced martensites
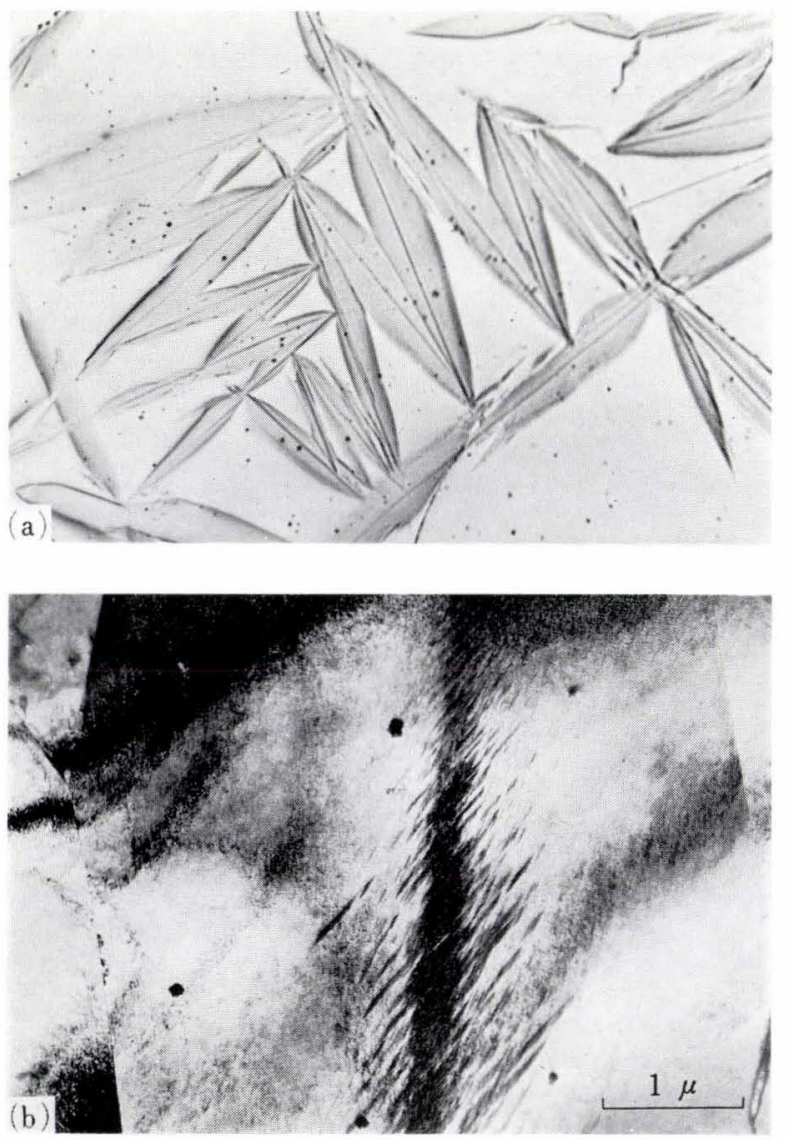

Photo. 1. Thermally transformed martensite in $\mathrm{Fe}-29 \% \mathrm{Ni}-$ $0.26 \% \mathrm{C}$ alloy cooled to $-60^{\circ} \mathrm{C}$

(a) Optical micrograph $(\times 400)(\times 1 / 2)$

(b) Transmission electron micrograph are very small and densely distributed in some directions. They are formed in localized areas and show a characteristic morphology in comparison with subzero martensite as shown in Photo. 1 (a). Photograph 2 (b) is another micrograph taken from the same specimens as in Photo. 2 (a). In this micrograph, a group of martensites looks like a bundle along one direction of the austenite grain. The interface of martensite is irregular. Thus, the shape of strain-induced martensite is like a flock of wild geese or butterflies, or like treetops of Japanese cedar. Though it seems in appearance that there are two types of strain-induced martensite as shown in Photos. 2 (a) and (b), it is considered, as the result of detailed observation of many microstructures, that this difference of morphology is caused by the difference of the cross section of martensite on the specimen surface.

Photograph 3 shows the transmission electron micrograph of strain-induced martensite formed during deformation at $-15^{\circ} \mathrm{C}$. In this martensite, the transformation twins and the mid-rib are not observed, but only dislocations. The dislocation density of retained austenite is high because of deformation. Photograph 4 (a) is also a transmission electron micrograph taken from the same specimen as in Photo. 3. Photographs 4 (b) and (c) are the electron diffraction patterns of the framed regions $A$ (martensite) and $B$ (austenite) in
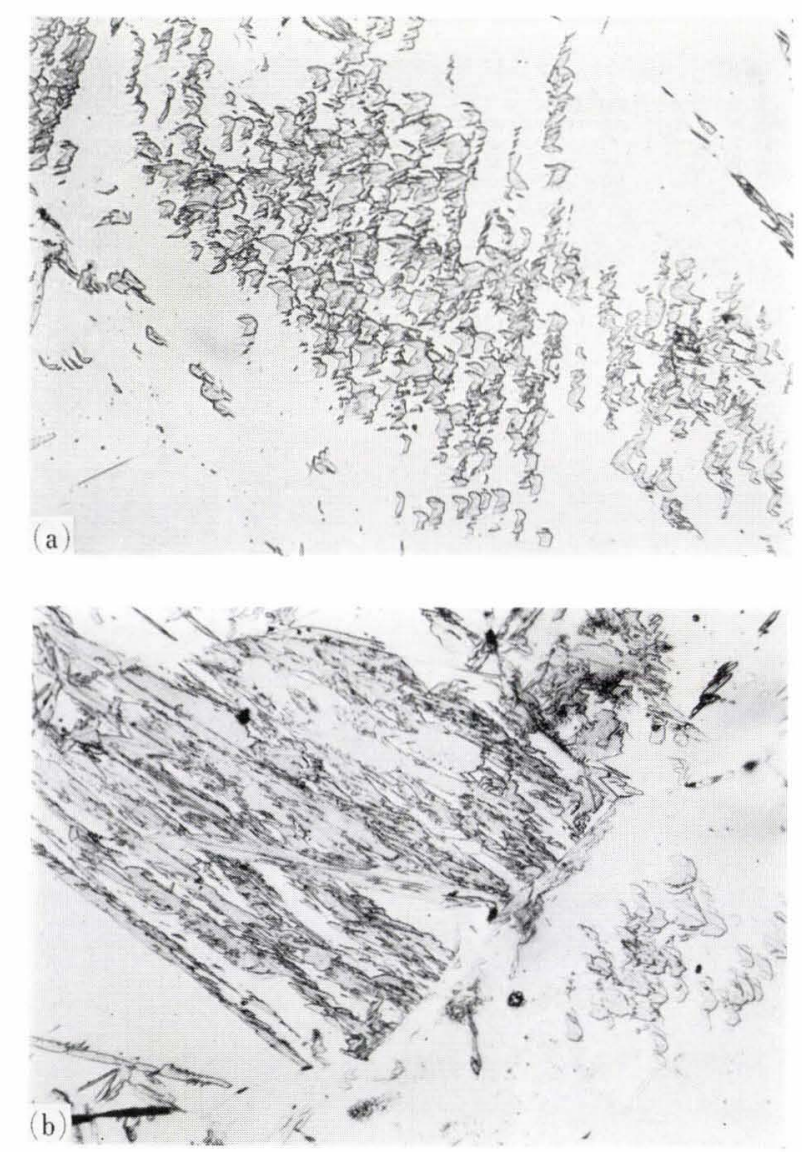

Photo. 2. Optical micrographs of strain-induced martensite in $\mathrm{Fe}-29 \% \mathrm{Ni}-0.26 \% \mathrm{C}$ alloy deformed $34 \%$ in tension at $-11^{\circ} \mathrm{C}(\times 400)(\times 1 / 2)$ 


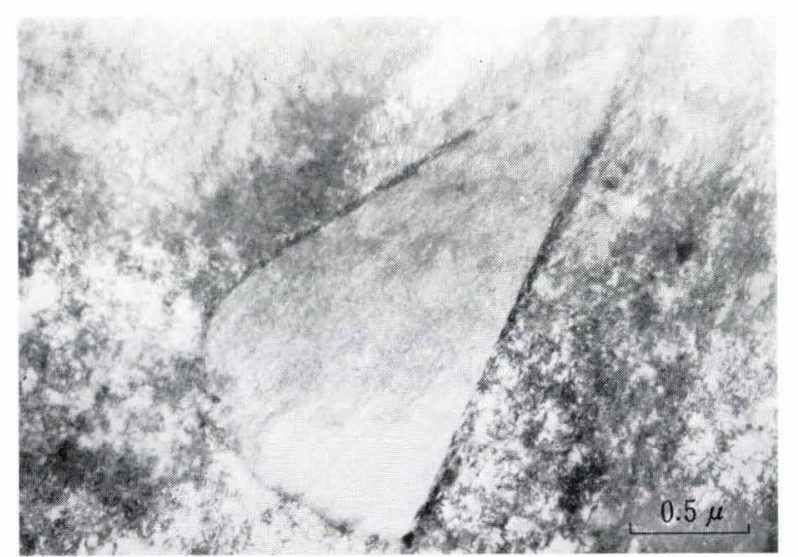

Photo. 3. Transmission electron micrograph of strain-induced martensite in $\mathrm{Fe}-29 \% \mathrm{Ni}-0.26 \% \mathrm{C}$ alloy deformed $47 \%$ in tension at $-15^{\circ} \mathrm{C}$

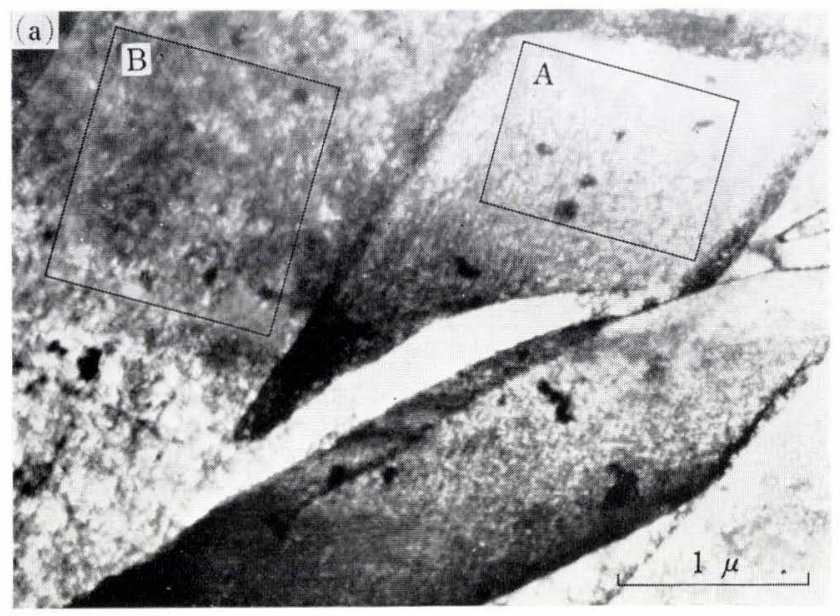

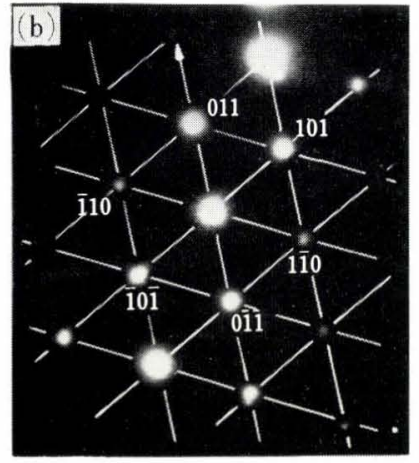

Beam $/ /[111] \alpha^{\prime}$

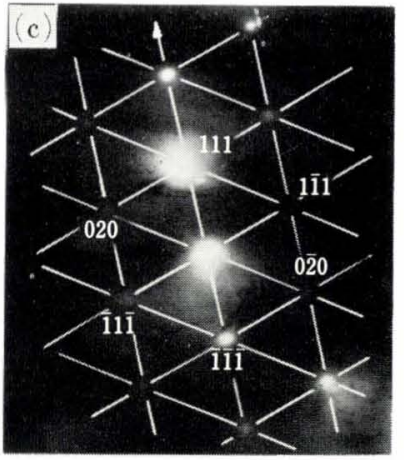

Beam // $[101] \gamma$
Photo. 4. (a) Transmission electron micrograph of strain-induced martensite in $\mathrm{Fe}-29 \% \mathrm{Ni}-0.26 \% \mathrm{C}$ alloy deformed $47 \%$ in tension at $-15^{\circ} \mathrm{C}$

(b) Diffraction pattern of the area $A$ (martensite) framed in micrograph (a)

(c) Diffraction pattern of the area $B$ (austenite) framed in micrograph (a)

Photo. 4 (a), respectively. It was confirmed from these diffraction patterns that the apparent orientation relationship between austenite and martensite was the $K-S$ type, namely $(011)_{\alpha^{\prime}} / /(111)_{\gamma},[\overline{11} 1]_{\alpha^{\prime}} / /[\overline{1} 01]_{\gamma}$, within accuracy of transmission electron diffraction.

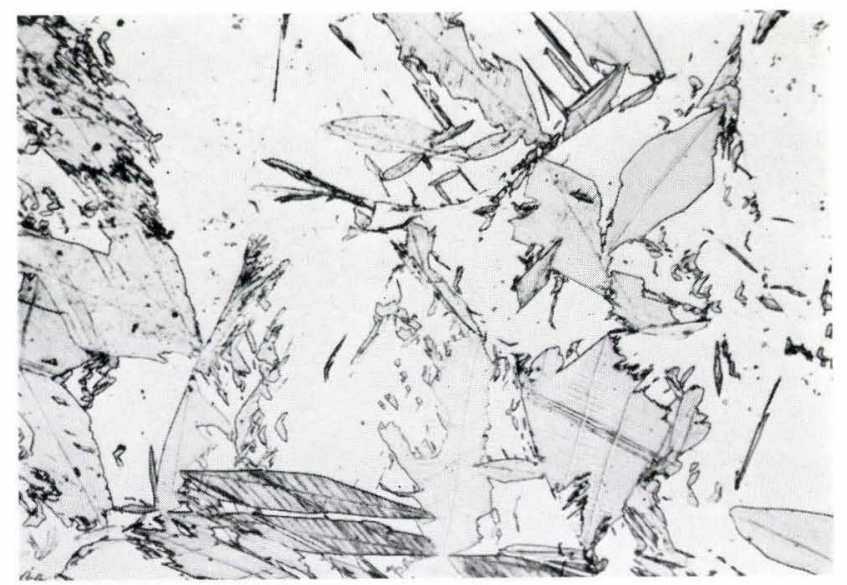

Photo. 5. Optical micrograph of strain-induced martensite in $\mathrm{Fe}-29 \% \mathrm{Ni}-0.26 \% \mathrm{C}$ alloy deformed in tension $23 \%$ at $-27^{\circ} \mathrm{C}(\times 300)(3 / 4)$

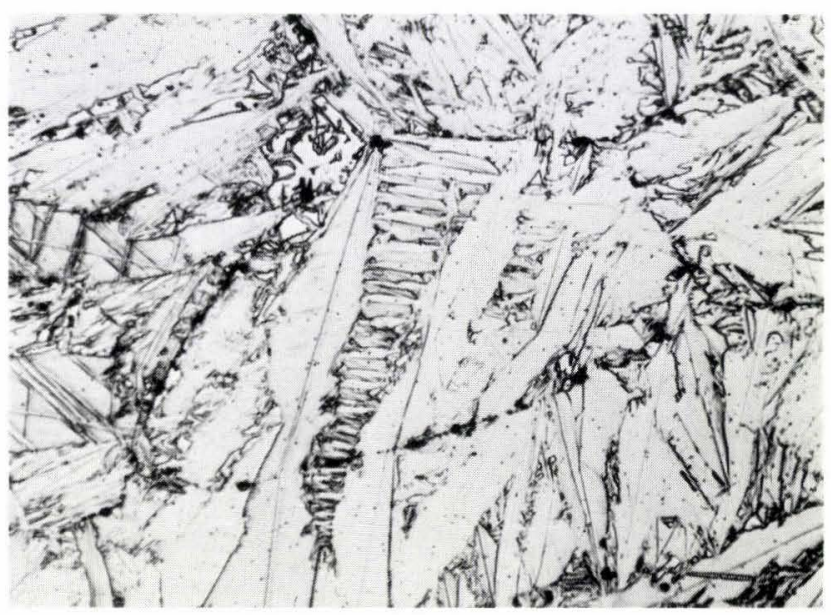

Photo. 6. Mixed structure of thermally transformed and straininduced martensite in $\mathrm{Fe}-29 \% \mathrm{Ni}-0.26 \% \mathrm{C}$ alloy deformed $21 \%$ in tension at $-60^{\circ} \mathrm{C}$ (below $\left.\mathrm{Ms}\right)(\times 425)$ $(3 / 4)$

The large plate-like strain-induced martensite with the same features as the subzero martensite shown in Photo. 1 (a) is also formed during deformation near Ms, even at temperatures above Ms. Photograph 5 shows an optical micrograph taken from the specimen deformed at $-27^{\circ} \mathrm{C}$ (just above Ms). The plate-like martensite with a mid-rib and the small and characteristic martensite as shown in Photo. 2 coexist in this micrograph. It was confirmed by the observation of microstructural change with strain that the former was formed at an early stage of deformation and then the latter was formed gradually with strain. Photograph 6 shows an example of the microstructure taken from an alloy deformed in tension at a temperature below Ms. This is the micrograph taken after deformation at $-60^{\circ} \mathrm{C}$. In this case, subzero martensites are already formed before the tensile test. By the tensile deformation at $-60^{\circ} \mathrm{C}$, plate-like martensites are formed in zigzag shape from retained austenite. The small and characteristic martensites as shown in Photo. 2 are also observed in this micrograph, though the amount of this characteristic martensite is small. 
This characteristic martensite, however, is no longer induced by the deformation at the temperatures below $-70^{\circ} \mathrm{C}$.

In $\mathrm{Fe}-31 \% \mathrm{Ni}$ alloy, it was observed that the small and characteristic martensite whose morphology was different from that of subzero martensite was also induced by deformation at temperatures between $\mathrm{Md}$ and $\mathrm{Ms}$ as well as in $\mathrm{Fe}-\mathrm{Ni}-\mathrm{C}$ alloy. Furthermore, the same change of morphology as in the $\mathrm{Fe}-\mathrm{Ni}-\mathrm{C}$ alloy was observed at all temperature ranges in the $\mathrm{Fe}-\mathrm{Ni}$ alloy.

\section{(2) Fe-Cr-Ni Alloy}

Photograph 7 shows the micrograph of $\mathrm{Fe}-15 \% \mathrm{Cr}-$ $13 \% \mathrm{Ni} \quad\left(\mathrm{Ms}=-58^{\circ} \mathrm{C}\right)$ after subzero-cooling to $-196^{\circ} \mathrm{C}$. In this alloy whose stacking fault energy of austenite is low, ${ }^{22)}$ hcp $\varepsilon^{\prime}$-martensite with $\{111\}_{\text {r }}$ habit plane is first formed ${ }^{6), 23), 24)}$ and then bcc $\alpha^{\prime}$-martensite is formed from austenite sectioned by $\varepsilon^{\prime}$-martensite. ${ }^{11), 25)}$ So, the groups of $\alpha^{\prime}$-martensite plates look like dark bands with $\{111\}_{\gamma}$ habit plane in Photo. 7. Each $\alpha^{\prime}$-martensite plate is very small. By the direct electron microscopic study, it was recognized that these

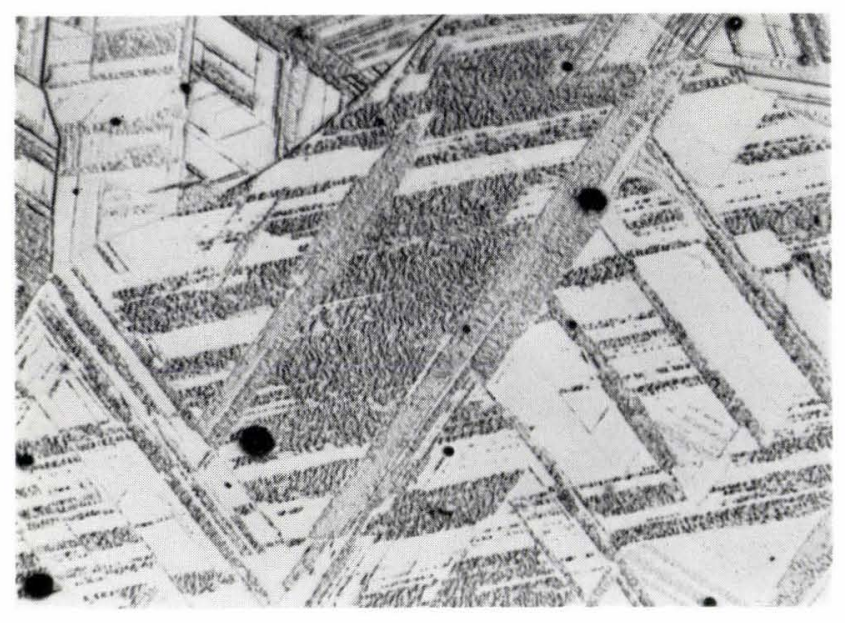

Photo. 7. Optical micrograph of thermally transformed martensite in $\mathrm{Fe}-15 \% \mathrm{Cr}-13 \% \mathrm{Ni}$ alloy cooled to $-196^{\circ} \mathrm{C}$ $(\times 300)(3 / 4)$

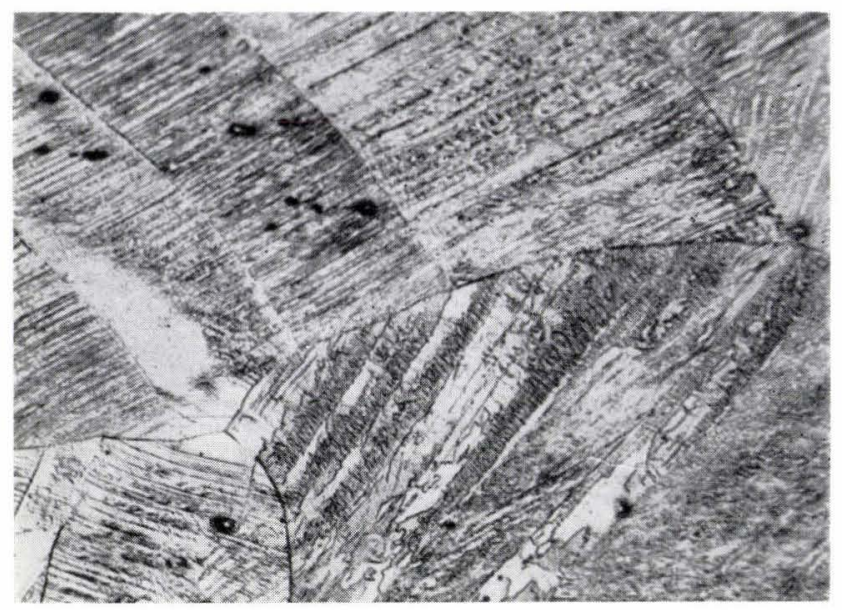

Photo. 8. Optical micrograph of strain-induced martensite in $\mathrm{Fe}-15 \% \mathrm{Cr}-13 \% \mathrm{Ni}$ alloy deformed $76 \%$ in tension at $-19^{\circ} \mathrm{C}(\times 300)(3 / 4)$ were lath untwinned martensites. Strain-induced martensites formed during deformation at $-19^{\circ} \mathrm{C}$ are shown in Photo. 8. The difference of morphology between the subzero martensite and strain-induced martensite is not clear.

\section{Transformation-Induced Plasticity}

\section{(1) $\mathrm{Fe}-\mathrm{Ni}-\mathrm{C}$ and $\mathrm{Fe}-\mathrm{Ni}$ Alloys}

Figure 2 shows typical stress-strain curves at various test temperatures in $\mathrm{Fe}-\mathrm{Ni}-\mathrm{C}$ alloy. Serrations are found in the curves tested at $-11^{\circ}$ to $-50^{\circ} \mathrm{C}$. These serrations result from the martensitic transformation during deformation. It is observed that the rate of strain-hardening increases in the serrated region. Very fine serrations are seen from about 20\% strain to near the fracture strain in the stress-strain curve obtained at $-11^{\circ} \mathrm{C}$, which gives the maximum elongation. With lowering test temperature from $-11^{\circ}$ to $-33^{\circ} \mathrm{C}$ (just above $\mathrm{Ms}$ ), serrations are getting larger and begin to appear at earlier strains. This implies that martensite is apt to be formed more in amount and at smaller strains with decreasing test temperature below Md. Particularly, at the temperature just above Ms, large serrations are observed even in the elastic strain range in the stress-strain curve. The martensite formed in such a region is plate-like martensite as shown in Photo. 5. On the contrary, with decreasing test temperature below Ms, the serrations become less to occur because the amount of retained austenite is on the decrease.

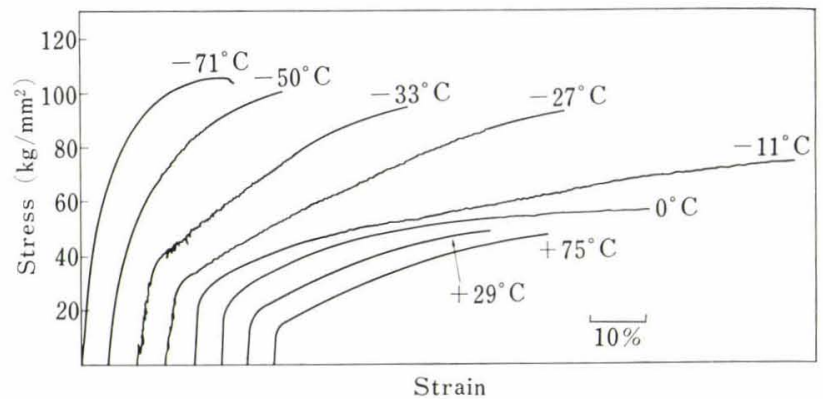

Fig. 2. Stress-strain curves of $\mathrm{Fe}-29 \% \mathrm{Ni}-0.26 \% \mathrm{C}$ alloy during tensile tests at various temperatures

Figure 3 shows the effect of test temperature on the tensile properties and average strain-hardening exponent ( $n$-value) in the strain range between 10 and $20 \%$. The $0.2 \%$ proof stress increases slightly with decreasing test temperature, and increases gradually below Ms because the amount of subzero martensite before tensile testing gradually increases. Tensile strength is almost constant above $\mathrm{Md}$, and increases rapidly with decreasing test temperature below $\mathrm{Md}$. Below Ms, the tensile strength gradually increases. On the other hand, the elongation is also constant above $\mathrm{Md}$, but increases rapidly from just below $\mathrm{Md}$ and has a maximum value at $-11^{\circ} \mathrm{C}$, then decreases abruptly with decreasing test temperature. The elongation decreases below Ms, but fairly large elongation is still found just below Ms because of strain-induced 


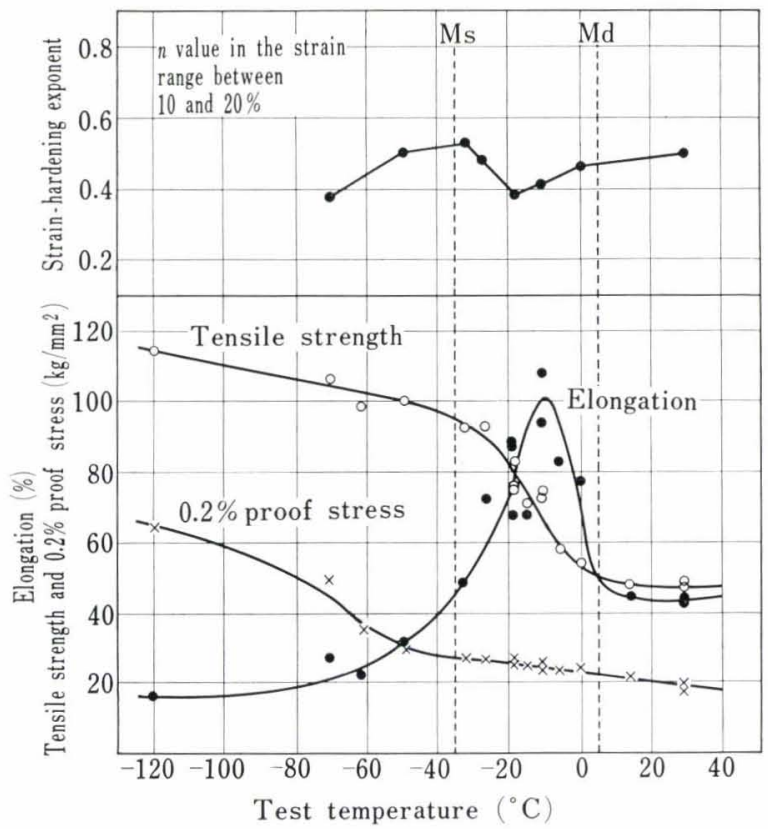

Fig. 3. Effect of test temperature on the tensile properties and the strain-hardening exponent in $\mathrm{Fe}-29 \% \mathrm{Ni}-0.26 \% \mathrm{C}$ alloy

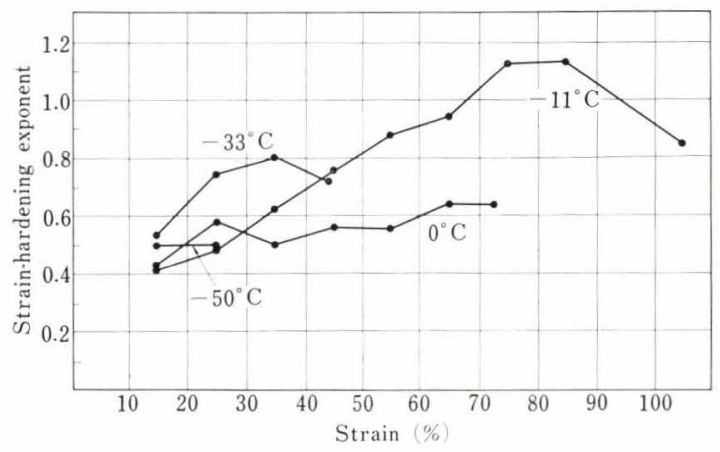

Fig. 4. Variations in the strain-hardening exponent with strain in $\mathrm{Fe}-29 \% \mathrm{Ni}-0.26 \% \mathrm{C}$ alloy

transformation of retained austenite. Thus, the peak of elongation is between $\mathrm{Md}$ and $\mathrm{Ms}$, and more than $100 \%$ elongation is observed at the peak. The strainhardening exponent in the strain range between 10 and $20 \%$ decreases slightly with decreasing test temperature and increases near Ms. Thus, at the temperature showing the maximum elongation, the strainhardening exponent in the strain range between 10 and $20 \%$ is low in comparison with other test temperatures. Figure 4 shows variations in the strain-hardening exponent with strain. In this case, the strainhardening exponent was obtained as an average value in each $10 \%$ strain range. While the strain-hardening exponent is almost constant or increases slightly at $0^{\circ}$ and $-50^{\circ} \mathrm{C}$ with increase in strain, it increases continuously with increase in strain in case of the test at $-11^{\circ} \mathrm{C}$ at which the maximum elongation is obtained. Such an increase in the strain-hardening exponent is closely connected with martensitic transformation during deformation. ${ }^{26)}$ In case of the test at $-11^{\circ} \mathrm{C}$, the martensite is constantly formed little by little with increase in strain up to the fracture strain. Photograph
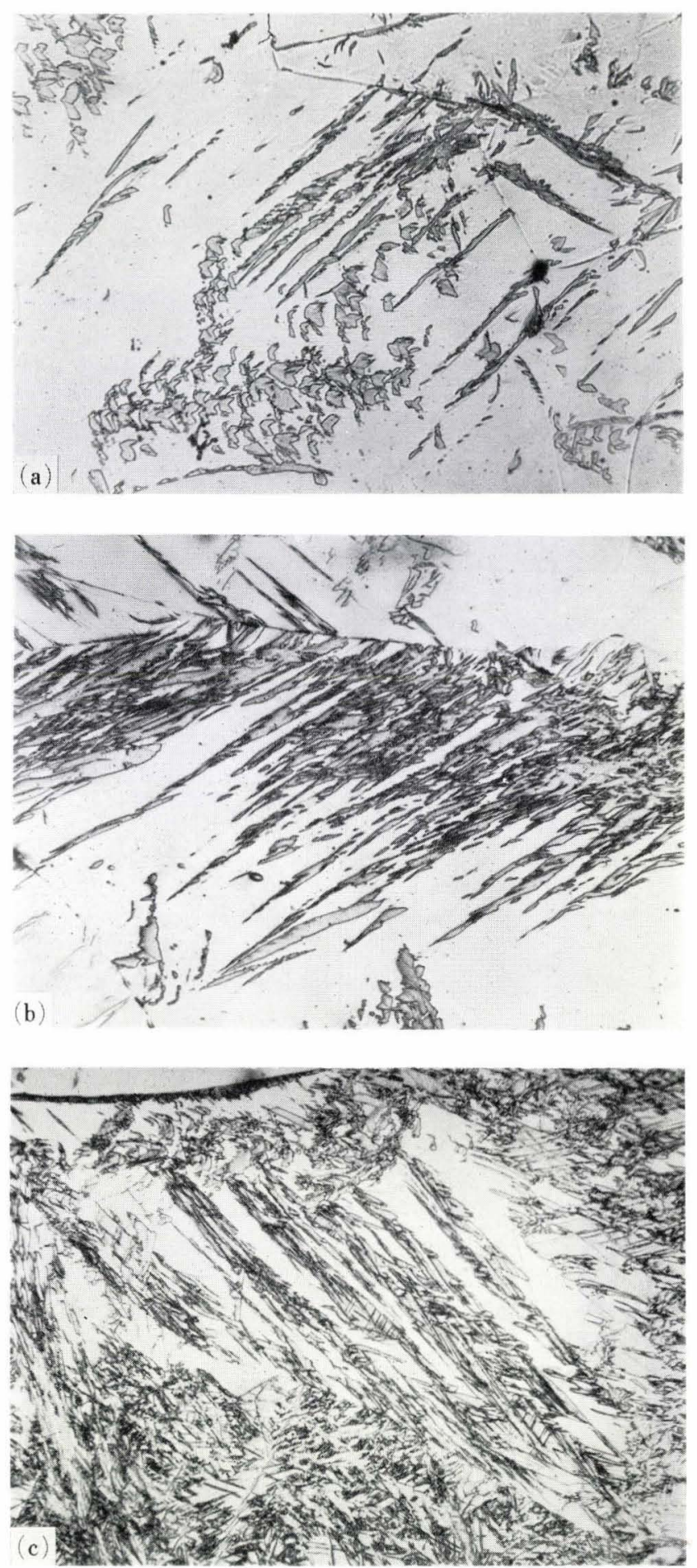

Photo. 9. Variations in optical microstructure with strain of $\mathrm{Fe}-29 \% \mathrm{Ni}-0.26 \% \mathrm{C}$ alloy deformed in tension at $-11^{\circ} \mathrm{C}(\times 300)(3 / 4)$
(a) Strain : $33.7 \%$
(b) Strain : $70.8 \%$
(c) Strain: $109.7 \%$

9 shows the increased amount of martensite with increase in strain. On the other hand, at $-33^{\circ} \mathrm{C}$, just above Ms, the strain-hardening exponent increases abruptly at small strains as shown in Fig. 4, which means that at this temperature a large amount of martensite is formed in the early stage of deformation. 


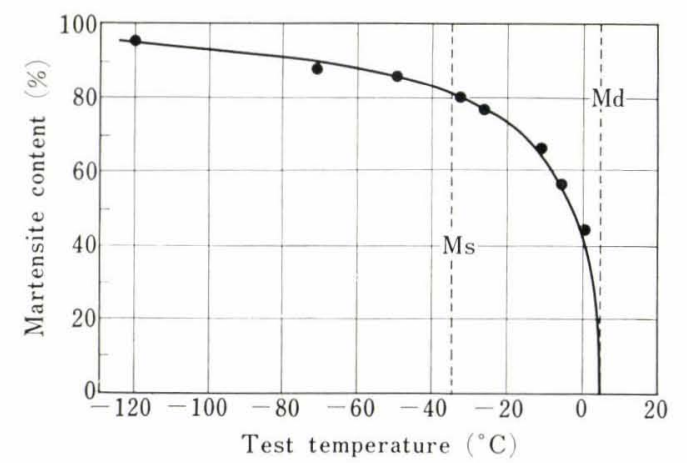

Fig. 5. Effect of test temperature on martensite content in $\mathrm{Fe}-$ $29 \% \mathrm{Ni}-0.26 \% \mathrm{C}$ alloy after tensile tests

Figure 5 shows the amount of martensite measured by X-ray using the specimens fractured at various temperatures. Though the extent of deformation to fracture is different at each test temperature, the amount of martensite after fracture increases with decreasing test temperature below Md. For example, the amount of martensite is $67 \%$ at $-11^{\circ} \mathrm{C}$, at which the maximum elongation (110\%) is obtained, and is $80 \%$ at $-33^{\circ} \mathrm{C} \mathrm{(50 \%} \mathrm{elongation)} \mathrm{just} \mathrm{above} \mathrm{Ms.} \mathrm{Thus,}$ the lower the test temperature is, the more martensite is formed. On the other hand, the elongation has a peak between Md and Ms, and decreases abruptly just above Ms. This is an important result, which shows that the elongation does not depend only on the amount of martensite formed during deformation. It is important that martensite is constantly formed, little by little, up to fracture strain. The change of tensile strength with test temperature shown in Fig. 3 corresponds well to martensite content after fracture. Consequently, it is suggested that tensile strength depends on martensite content as reported previously. ${ }^{14), 15)}$

Figure 6 shows the effect of test temperature on the tensile properties and average strain-hardening exponent in the strain range between 10 and $20 \%$ in $\mathrm{Fe}-31 \% \mathrm{Ni}$ alloy. The elongation shows also a remarkable peak at a temperature between $\mathrm{Md}$ and $\mathrm{Ms}$ in this alloy. Furthermore, the $0.2 \%$ proof stress, tensile strength, and strain-hardening exponent show the same behavior as in the $\mathrm{Fe}-\mathrm{Ni}-\mathrm{C}$ alloy. Figure 7 shows variations in strain-hardening exponent with strain. It is seen to have a similar characteristic in that the strain-hardening exponent increases continuously with increase in strain in case of the test at $-37^{\circ} \mathrm{C}$ at which the maximum elongation is obtained.

\section{(2) $\mathbf{F e}-\mathrm{Cr}-\mathrm{Ni}$ Alloy}

Figure 8 shows the typical stress-strain curves at various test temperatures for the $\mathrm{Fe}-15 \% \mathrm{Cr}-13 \% \mathrm{Ni}$ alloy. Though serrations hardly occur in this alloy, it is noted that the rate of strain-hardening increases with strain because of martensitic transformation during deformation, as represented at $-52^{\circ} \mathrm{C}$ just above Ms.

Figure 9 shows the effect of test temperature on the tensile properties and average strain-hardening exponent in the strain range between 10 and $20 \%$.

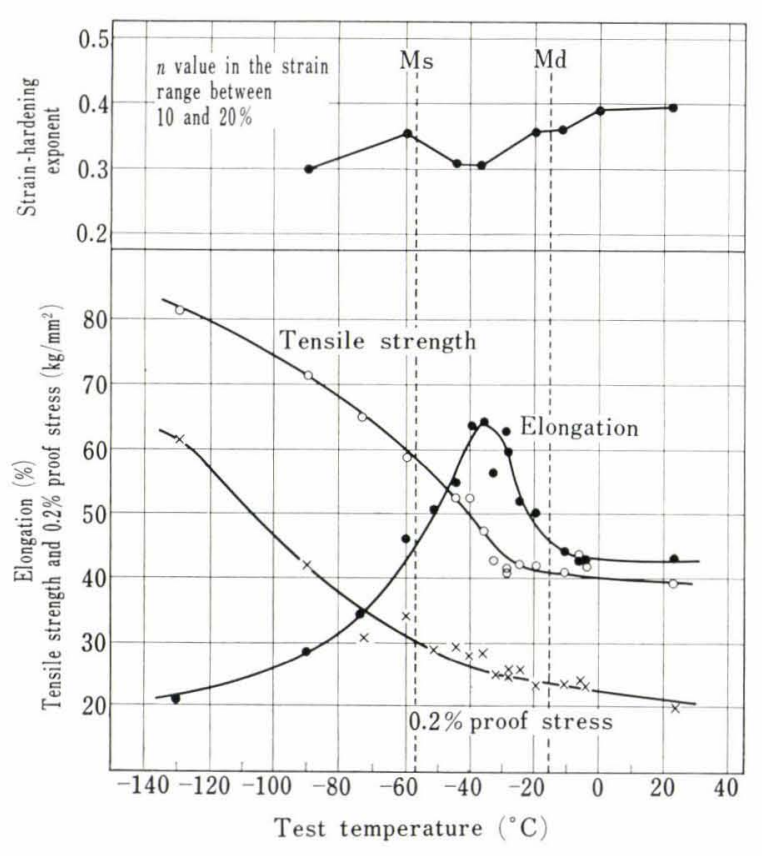

Fig. 6. Effect of test temperature on the tensile properties and the strain-hardening exponent in $\mathrm{Fe}-31 \% \mathrm{Ni}$ alloy

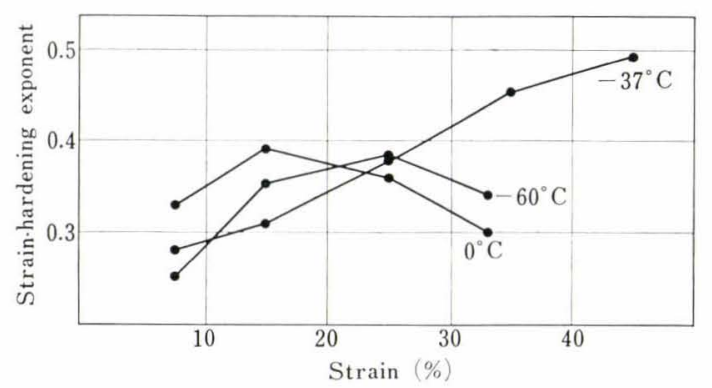

Fig. 7. Variations in the strain-hardening exponent with strain in $\mathrm{Fe}-31 \% \mathrm{Ni}$ alloy

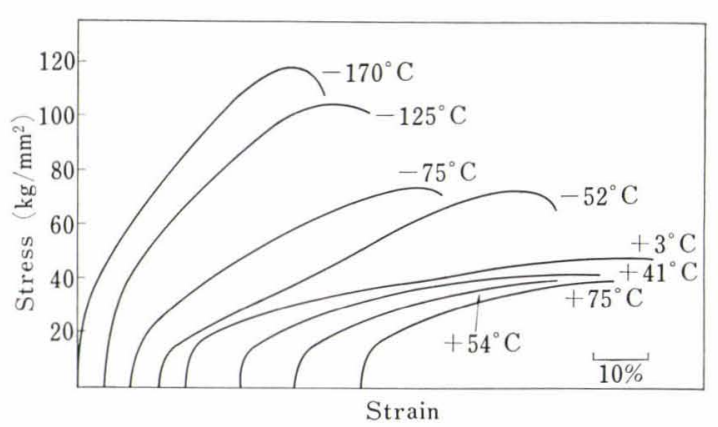

Fig. 8. Stress-strain curves of $\mathrm{Fe}-15 \% \mathrm{Cr}-13 \% \mathrm{Ni}$ alloy during tensile tests at various temperatures

The elongation shows a peak between Md and Ms as in the $\mathrm{Fe}-\mathrm{Ni}$ alloys. It is, however, different from $\mathrm{Fe}-\mathrm{Ni}$ alloys in that the temperature range showing large elongation is wider in the $\mathrm{Fe}-\mathrm{Cr}-\mathrm{Ni}$ alloy than in $\mathrm{Fe}-\mathrm{Ni}$ alloys, and also the elongation is high below Ms in $\mathrm{Fe}-\mathrm{Cr}-\mathrm{Ni}$ alloy, though in $\mathrm{Fe}-\mathrm{Ni}$ alloys the elongation decreases rapidly below $\mathrm{Ms}$. The $0.2 \%$ proof stress increases slightly with decreasing test temperature, but does not so continue to increase below Ms as 


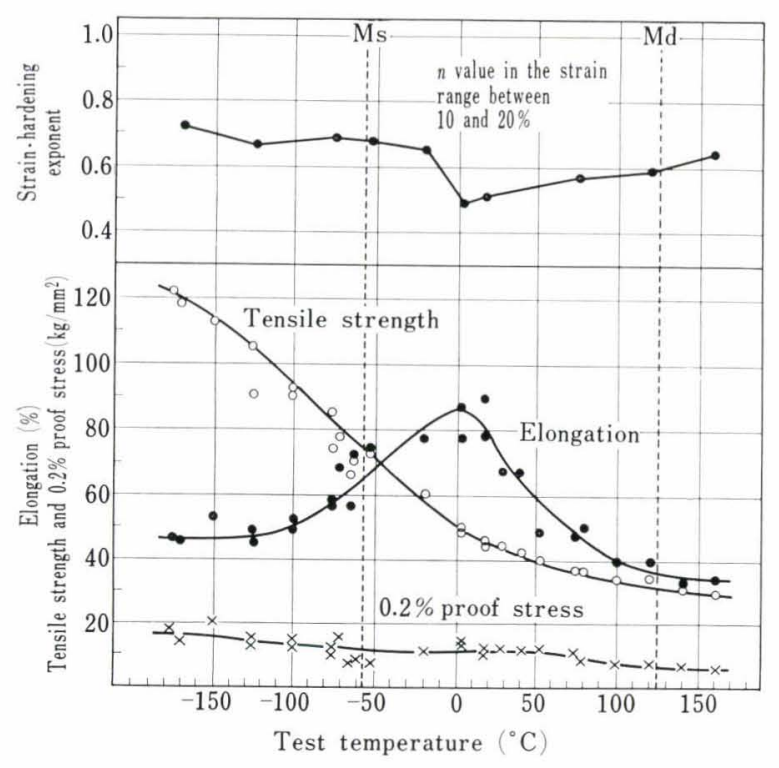

Fig. 9. Effect of test temperature on the tensile properties and the strain-hardening exponent in $\mathrm{Fe}-15 \% \mathrm{Cr}-13 \% \mathrm{Ni}$ alloy

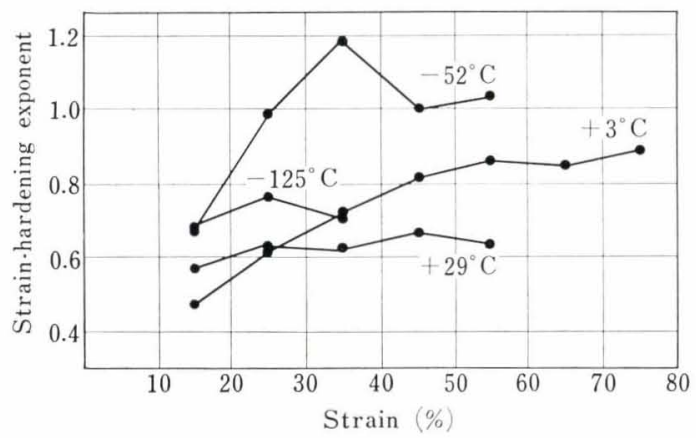

Fig. 10. Variations in the strain-hardening exponent with strain in $\mathrm{Fe}-15 \% \mathrm{Cr}-13 \% \mathrm{Ni}$ alloy

Fe-Ni alloys do. The tensile strength shows a similar behavior to $\mathrm{Fe}-\mathrm{Ni}$ alloys. With decreasing test temperature the strain-hardening exponent decreases slowly up to $3^{\circ} \mathrm{C}$ at which the maximum elongation is obtained, and increases near Ms, then is almost constant below Ms. Figure 10 shows variations in the strainhardening exponent with strain. As with $\mathrm{Fe}-\mathrm{Ni}$ alloys, the strain-hardening exponent increases continuously with increase in strain in case of the test at $3^{\circ} \mathrm{C}$ at which the maximum elongation is obtained.

\section{Discussion}

\section{The Morphology of Strain-Induced Martensite}

It was demonstrated that a characteristic martensite whose morphology was entirely different from that of subzero martensite was induced during deformation of $\mathrm{Fe}-\mathrm{Ni}$ alloys at temperatures between $\mathrm{Md}$ and $\mathrm{Ms}$. Such a phenomenon has not previously been reported. It is necessary to make clear whether the character of morphology is unique for martensite formed during deformation or not. It is considered that the morphology of strain-induced martensite may be affected

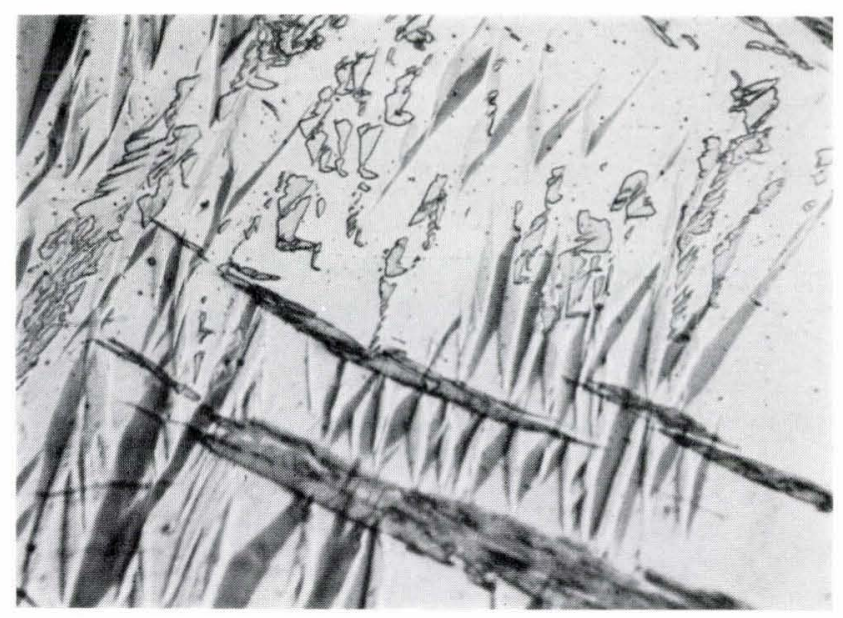

Photo. 10. Mixed structure of strain-induced and ausformed martensite in $\mathrm{Fe}-29 \% \mathrm{Ni}-0.26 \% \mathrm{C}$ alloy deformed $73 \%$ in tension at $-11^{\circ} \mathrm{C}$, and then cooled to $-60^{\circ} \mathrm{C}$. Ausformed martensite is recognized as surface relief. $(\times 425)(3 / 4)$

by the following two effects: that is, (1) the effect of ausforming and (2) the effect of deformation of martensite. It has been reported ${ }^{27)}$ that ausformed martensite is not essentially different from subzero martensite though the martensite plate becomes fine and the boundary of martensite plate becomes somewhat irregular by ausforming. To confirm this effect, the next experiment was run. After deformation of $71 \%$ in tension at $-11^{\circ} \mathrm{C}$, the specimen of $\mathrm{Fe}-\mathrm{Ni}-\mathrm{C}$ alloy was polished and etched, then cooled to $-60^{\circ} \mathrm{C}$. Photograph 10 is the optical micrograph taken from such a specimen. In this photograph, strain-induced martensites, and subzero martensites (ausformed martensite) can be clearly distinguished one from the other, because the strain-induced martensites appear as the normal etched structure and the ausformed martensites are recognized as the surface relief. The ausformed martensite formed from heavily deformed austenite is plate-like, and is quite different from straininduced martensite. It is, therefore, considered that the morphology of strain-induced martensite is hardly affected by the ausforming. Next, the effect of deformation of martensite was investigated. Photograph 11 shows the micrograph taken from a specimen of $\mathrm{Fe}-\mathrm{Ni}-\mathrm{C}$ alloy cooled to $-60^{\circ} \mathrm{C}$ and then deformed $28 \%$ in tension at room temperature (above $\mathrm{Md}$ ). It is clear that the morphology of subzero martensites is hardly changed by deformation, though deformation twins are produced in the martensite plates. So, it is hardly expected that the morphology of strain-induced martensite would be affected by deformation subsequent to its formation. Then, it is concluded that the morphology of the characteristic strain-induced martensite is different from that of ausformed martensite and/or deformed martensite, and is unique.

Subzero martensite of $\mathrm{Fe}-\mathrm{Ni}$ alloys used in this investigation was typically plate-like partially twinned martensite with a mid-rib as shown in Photo. 1, and was formed in bursts. Thus, it is presumed from the previous reports ${ }^{28)}{ }^{29)}$ that this martensite is the Um- 


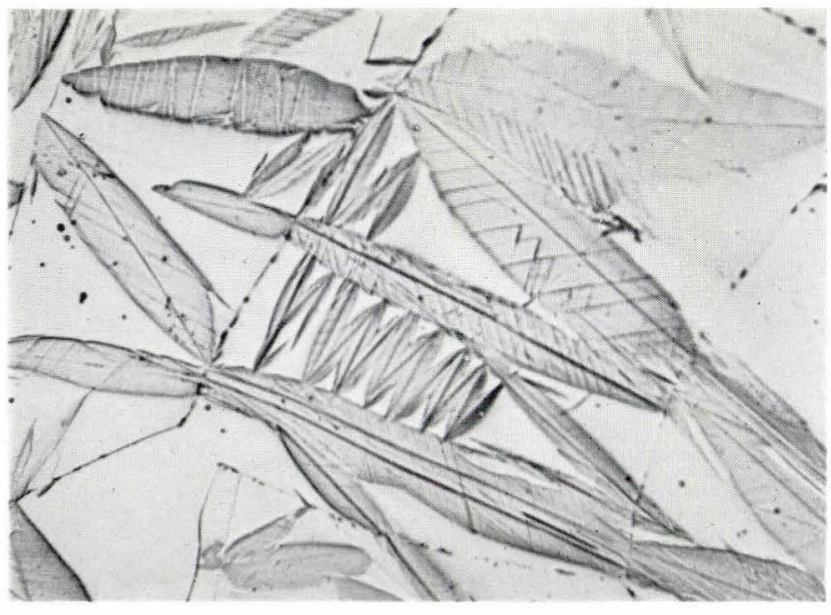

Photo. 11. Optical micrograph of deformed martensite in $\mathrm{Fe}-$ $29 \% \mathrm{Ni}-0.26 \% \mathrm{C}$ alloy cooled to $-196 \mathrm{C}$ and then deformed $28 \%$ in tension at room temperature $(X 400)$ $(3 / 4)$

klapp martensite whose orientation relationship with austenite is the $\mathcal{N}$-type and whose habit plane is $\{259\}$. On the other hand, the characteristic strain-induced martensite as shown in Photo. 2 had only numerous dislocations and no transformation twins as lattice imperfections in martensite. Moreover, the orientation relationship between martensite and austenite was confirmed to be nearly the $K-S$ type. From these results, it is considered that this martensite is the socalled Schiebung martensite. ${ }^{30}$ ) The transformation mechanism of strain-induced martensite may be different from that of subzero martensite. Patterson et al. ${ }^{20)}$ have suggested that, in $\mathrm{Fe}-\mathrm{Ni}$ partially twinned martensite, Umklapp transformation occurs in the twinned region and Schiebung transformation in the untwinned region. In the present investigation, the substructure of strain-induced martensite shown in Photo. 3 was similar to that of the untwinned region of subzero martensite shown in Photo. 1 (b). Honma ${ }^{31}$ ) has reported that the Umklapp and Schiebung martensites coexist in $\mathrm{Fe}-25$ to $30 \% \mathrm{Ni}$ alloys, and the Schiebung transformation occurs at higher temperature than Umklapp transformation (the upper critical temperature of Umklapp transformation is about $-10^{\circ} \mathrm{C}$ ). Considering the results in this investigation and the previous reports ${ }^{20), 31)}$ as mentioned above, it is expected that the Schiebung transformation may occur when martensite is induced during deformation at temperatures above Ms, even if subzero martensite is the Umklapp type. Therefore, the change of morphology of martensite in $\mathrm{Fe}-\mathrm{Ni}$ alloys observed in this investigation may be due to the change of transformation mechanism. It is, however, not clear whether strain-induced martensite formed at temperatures above Ms is always the Schiebung type or not in case of $\mathrm{Fe}-\mathrm{Ni}$ alloys whose $\mathrm{Ms}$ temperature is very low, because, judging from a previous report, ${ }^{31)}$ it is considered that the Schiebung transformation hardly occurs at very low temperatures. Reed ${ }^{32}$ ) has examined the morphology of $\mathrm{Fe}-\mathrm{Ni}$ plate-like martensite, and shown that strain-induced martensite formed by de- formation at $-196^{\circ} \mathrm{C}$ in an $\mathrm{Fe}-35 \% \mathrm{Ni}$ alloy $(\mathrm{Ms}<$ $-196^{\circ} \mathrm{C}$ ) is plate-like. His result may be due to the fact that the deformation temperature was very low $\left(-196^{\circ} \mathrm{C}\right)$, so the Schiebung transformation did not occur. On the other hand, no difference was observed in morphology between subzero martensite and strain-induced martensite in the $\mathrm{Fe}-\mathrm{Cr}-\mathrm{Ni}$ alloy. In this alloy whose stacking fault energy of austenite is low in comparison with $\mathrm{Fe}-\mathrm{Ni}$ alloys, subzero martensite essentially belongs to the Schiebung martensite. Thus it is considered that the morphology does not change for subzero martensite and strain-induced martensite, because these transformation mechanisms are identical in the $\mathrm{Fe}-\mathrm{Cr}-\mathrm{Ni}$ alloy.

\section{Plasticity Induced by Martensitic Transformation}

Both in $\mathrm{Fe}-\mathrm{Ni}$ alloys and in $\mathrm{Fe}-\mathrm{Cr}-\mathrm{Ni}$ alloy, an unusually large elongation was observed at a certain temperature range between $\mathrm{Md}$ and $\mathrm{Ms}$, especially in the $\mathrm{Fe}-\mathrm{Ni}-\mathrm{C}$ alloy where more than $100 \%$ elongation was obtained. Such a phenomenon can be regarded as a kind of super-plasticity. ${ }^{33), 34)}$ The phenomenon of usual super-plasticity mainly occurs at high temperature and vacancies play an important role. However, in the case of transformation-induced plasticity by martensite formation during deformation, the contribution of vacancies may be almost negligible because this phenomenon occurs at low temperature. This unusual elongation mainly results from the martensitic transformation during deformation. It was clear in Fig. 5, however, that elongation did not necessarily depend only on the total amount of martensite formed, but also on the conditions of martensite formation; namely the time (strain) at which martensite was formed, the shape of martensite, the amount of martensite, etc. Judging from the analysis of the variations in strain-hardening exponent and of serrations in stressstrain curves, the prerequisite for maximum elongation is that the deformation of austenite occurs at early stages of deformation without martensitic transformation and then martensite is constantly formed little by little during deformation up to fracture.

The following two points can be considered as the main reason why a large elongation is obtained when martensites are constantly formed during deformation. First suppression of necking is considered. Generally, as is well known, it is difficult to produce necking in material having a large strain-hardening exponent, consequently it shows a large uniform elongation. In the case when martensite is formed little by little during deformation as shown in the present investigation, the strain-hardening exponent increases continuously with increase in strain and at last reaches a much larger value than that of austenite at the large strain near fracture. Therefore, if micro-necking takes place during deformation, the necked region is hardened more by strain-induced martensite than the rest of the specimen, so the incipient necking no longer grows, and then deformation occurs in the adjacent region. Consequently, uniform elongation becomes larger when martensite is formed gradually during deformation than in deformation of only austenite above Md. The 
increase in the strain-hardening exponent is, however, due to the hardening mainly caused by the formation of strain-induced martensite, and so is not due only to the usual strain-hardening which is observed in simple one phase alloys (in this case, the strain-hardening exponent is almost constant over the entire strain range). The fact that necking is suppressed by martensitic transformation has been pointed out in the previous investigations of stainless steels by Bressanelli et al., ${ }^{14)}$ Fukase et al.. ${ }^{15)}$ Zackay et al., ${ }^{16)}$ and Ludwigson et al. ${ }^{35)}$

Secondly, the suppression of the initiation and the propagation of microcracks should be considered. The above-mentioned discussion will be out of the question if microcracks initiate easily and propagate to the fracture at an early stage of deformation. The stress concentration may be relaxed by the formation of martensite at the region where the stress concentration is caused during deformation, and then the initiation of microcracks may be prevented. Furthermore, even if microcracks are initiated, martensite formed at the tips of microcracks will relax the stress concentration and suppress their propagation. ${ }^{36), 37)}$ By reason of these, it is considered that the initiation and the propagation of microcracks are more difficult to take place than in alloys having a single austenite phase. Thus, transformation-induced plasticity may be caused by the suppression of necking, and the suppression of the initiation and the propagation of microcracks. Therefore, martensite which is constantly formed little by little by deformation efficiently contributes to the enhancement of elongation. On the other hand, elongation is not so large in cases where martensite is plentifully formed in the early stage of deformation as just above Ms, or in cases where the total amount of martensite formed is too small as just below Md. Consequently, it follows that elongation shows a peak at a certain temperature between $\mathrm{Md}$ and Ms.

The main difference between $\mathrm{Fe}-\mathrm{Ni}$ alloys and $\mathrm{Fe}-$ $\mathrm{Cr}-\mathrm{Ni}$ alloy is in the temperature difference between $\mathrm{Md}$ and Ms. It is about $40^{\circ} \mathrm{C}$ in $\mathrm{Fe}-\mathrm{Ni}$ alloys, but about $180^{\circ} \mathrm{C}$ in $\mathrm{Fe}-\mathrm{Cr}-\mathrm{Ni}$ alloy. This may result from the fact that $\varepsilon^{\prime}$-martensite is easily formed by deformation in $\mathrm{Fe}-\mathrm{Cr}-\mathrm{Ni}$ alloy whose stacking fault energy of

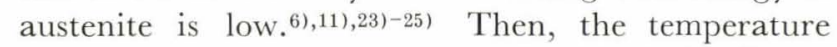
range showing a large elongation is wider in $\mathrm{Fe}-\mathrm{Cr}-\mathrm{Ni}$ alloy than in $\mathrm{Fe}-\mathrm{Ni}$ alloys. It is considered that $\varepsilon^{\prime}-$ martensite is first formed by deformation below $\mathrm{Md}$ and that $\alpha^{\prime}$-martensitic transformation is accelerated by the formation of $\varepsilon^{\prime}$-martensite, so $\alpha^{\prime}$-martensite contributes to the increased elongation. And it may be also considered that $\varepsilon^{\prime}$-martensite itself contributes to higher elongation.

$\mathrm{Fe}-\mathrm{Cr}-\mathrm{Ni}$ alloy shows a fairly large elongation even at temperatures below $\mathrm{Ms}$, though in the case of $\mathrm{Fe}-\mathrm{Ni}$ alloys the elongation decreases rapidly below Ms. This may result from the difference in the amount of retained austenite prior to tensile testing and the difference of the conditions of martensite formation during deformation. Subzero martensite of $\mathrm{Fe}-\mathrm{Ni}$ alloys used in this work is formed in bursts. On the other hand, in the case of the $\mathrm{Fe}-\mathrm{Cr}-\mathrm{Ni}$ alloy, martensitic transformation does not occur in bursts, and the amount of martensite produced on cooling is less than that in $\mathrm{Fe}-\mathrm{Ni}$ alloys. The amount of martensite formed by cooling to $-196^{\circ} \mathrm{C}$ after austenitization was determined by $\mathrm{X}$-ray analysis. The result obtained was that the amount of martensite was $95 \%$ in $\mathrm{Fe}-\mathrm{Ni}-\mathrm{C}$ alloy and $40 \%$ in $\mathrm{Fe}-\mathrm{Cr}-\mathrm{Ni}$ alloy. Thus, the amount of retained austenite prior to testing is more in the $\mathrm{Fe}-$ $\mathrm{Cr}-\mathrm{Ni}$ alloy than in $\mathrm{Fe}-\mathrm{Ni}$ alloys. This is also confirmed by the fact that the $0.2 \%$ proof stress changes only slightly below $\mathrm{Ms}$ in the $\mathrm{Fe}-\mathrm{Cr}-\mathrm{Ni}$ alloy as shown in Fig. 9, though in $\mathrm{Fe}-\mathrm{Ni}$ alloys it increases rather rapidly. When martensites are produced from retained austenite during deformation below $\mathrm{Ms}$, the martensites of $\mathrm{Fe}-\mathrm{Ni}$ alloys are formed in bursts at an early stage of deformation as shown in Photo. 6, but in the case of $\mathrm{Fe}-\mathrm{Cr}-\mathrm{Ni}$ alloy martensites are formed gradually with strain. Thus, it is considered that fairly large transformation-induced plasticity occurs even at temperatures below $\mathrm{Ms}$ in the $\mathrm{Fe}-\mathrm{Cr}-\mathrm{Ni}$ alloy. The occurrence of transformation-induced plasticity may be greatly affected by the transformation behavior of martensite.

\section{Summary}

In order to study the morphology of strain-induced martensite and the plasticity induced by the martensitic transformation, tensile tests at various temperatures and the observation of microstructures were carried out using $\mathrm{Fe}-\mathrm{Ni}-\mathrm{C}, \mathrm{Fe}-\mathrm{Ni}$, and $\mathrm{Fe}-\mathrm{Cr}-\mathrm{Ni}$ alloys whose Ms temperatures were below room temperature. The results obtained are summarized as follows.

(1) In $\mathrm{Fe}-\mathrm{Ni}$ alloys, the small and characteristic martensite whose morphology is entirely different from that of subzero martensite is formed densely in certain directions by tensile deformation. This martensite is induced during deformation mainly at temperatures between Md and Ms though there is a small amount of martensite formed below Ms. It was confirmed that the morphology of strain-induced martensite was different from that of ausformed and/or deformed martensite. Subzero martensite of $\mathrm{Fe}-\mathrm{Ni}$ alloys is platelike partially twinned martensite with a mid-rib and is formed in bursts. On the other hand, the characteristic strain-induced martensite is untwinned, and has high dislocation density. The crystallographic orientation relationship between austenite and strain-induced martensite is nearly the $K-S$ type. The difference of morphology between the subzero martensite and strain-induced martensite may be caused by the change of transformation mechanism. The characteristic strain-induced martensite is formed constantly with increase in strain and contributes to transformation-induced plasticity. In $\mathrm{Fe}-\mathrm{Ni}$ alloys, however, the same plate-like martensite with a mid-rib as subzero martensite is also formed at early stages of deformation at temperatures below Ms or just above Ms.

In the case of the $\mathrm{Fe}-\mathrm{Cr}-\mathrm{Ni}$ alloy, no difference of morphology between subzero martensite and straininduced martensite is observed. For this reason, it is considered that the transformation mechanism does not change among two kinds of martensites in $\mathrm{Fe}-\mathrm{Cr}-$ $\mathrm{Ni}$ alloy. 
(2) Transformation-induced plasticity occurs typically in $\mathrm{Fe}-\mathrm{Ni}$ alloys as well as in the $\mathrm{Fe}-\mathrm{Cr}-\mathrm{Ni}$ alloys reported previously. In particular, the maximum elongation obtained in $\mathrm{Fe}-\mathrm{Ni}-\mathrm{C}$ alloy is more than $100 \%$. A similar elongation behavior is observed in both $\mathrm{Fe}-\mathrm{Ni}$ alloys and the $\mathrm{Fe}-\mathrm{Cr}-\mathrm{Ni}$ alloy. Elongation has the maximum value at a temperature between Md and Ms. In the tests in which the maximum elongation is obtained, the strain-hardening exponent increases continuously with increased strain. The main condition for the maximum elongation is that the martensite is constantly formed little by little during deformation up to fracture. When martensite is formed in bursts at early stages of deformation, the elongation is not so large. Elongation does not simply depend on the total amount of martensite induced during deformation, but also on the conditions of martensite formation (strain, morphology, amount, and so on). It is considered that the main cause of the large elongation is the enhancement of uniform elongation due to the suppression of necking, and of initiation and propagation of microcracks connected with relaxation of stress concentration by the formation of strain-induced martensite.

The difference between $\mathrm{Fe}-\mathrm{Ni}$ alloys and the $\mathrm{Fe}-$ $\mathrm{Cr}-\mathrm{Ni}$ alloy is that the temperature range showing a large elongation is wider in the $\mathrm{Fe}-\mathrm{Cr}-\mathrm{Ni}$ alloy than in Fe-Ni alloys. This is caused by the difference of transformation behavior of martensite.

\section{REFERENCES}

1) M. Okamoto and R. Odaka: J. Japan Inst. Metals, 18 (1954), 392.

2) T. Angel: J. Iron Steel Inst., 177 (1954), 165.

3) G. W. Form and W. M. Baldwin: Trans. Amer. Soc. Metals, 48 (1956), 474.

4) Z. Nishiyama, K. Shimizu, and M. Oka: J. Japan Inst. Metals, 22 (1958), 532.

5) G. W. Powell, E. R. Marshall, and A. Backofen: Trans. Amer. Soc. Metals, 50 (1958), 498.

6) C. J. Guntner and R. P. Reed: Trans. Amer. Soc. Metals, 55 (1962), 399.

7) H. C. Fiedler, B. L. Averbach, and M. Cohen: Trans. Amer. Soc. Metals, 47 (1955), 267.
8) H. M. Otte: Acta Met., 5 (1957), 614

9) B. Cina: Acta Met., 6 (1958), 748.

10) J. F. Breedis and W. D. Robertson: Acta Met., 11 (1963), 547.

11) R. Lagneborg: Acta Met., 12 (1964), 823.

12) R. P. Reed and C. J. Guntner: Trans. AIME, 230 (1964), 1713.

13) C. H. White and R. W. K. Honeycombe: J. Iron Steel Inst., 200 (1962), 457.

14) J. P. Bressanelli and A. Moskowitz: Trans. Amer. Soc. Metals, 59 (1966), 223.

15) Y. Fukase, K. Ebato, N. Okubo, and S. Murao: J. Japan Inst. Metals, 32 (1968), 38.

16) V. F. Zackay, E. R. Parker, D. Fahr, and R. Busch: Trans. Amer. Soc. Metals, 60 (1967), 252.

17) W. W. Gerberich, P. L. Hemmings, M. D. Merz, and V. F. Zackay: Trans. Amer. Soc. Metals, 61 (1968), 843.

18) E. J. Dulis and V. K. Chandhok: Metal Prog., 95 Jan. (1969), 101.

19) G. R. Speich and P. R. Swann: J. Iron Steel Inst., 203 (1965), 480.

20) R. L. Patterson and C. M. Wayman: Acta Met., 14 (1966), 347.

21) M. R. Jackson and G. Krauss: Advances in Electron Metallography, 6 (1966), 62.

22) J. F. Breedis: Trans. AIME, 230 (1964), 1583.

23) J. A. Venables: Phil. Mag., 2 (1962), 35.

24) Z. Nishiyama, K. Shimizu, and S. Morikawa: J. Japan Inst. Metals, 27 (1963), 497.

25) R. P. Reed: Acta Met., 10 (1962), 865.

26) C. K. Divers: Metal Prog., 86 No. 2 (1964), 115.

27) I. Tamura, H. Yoshimura, M. Ibaraki, and M. Tagaya: J. Japan Inst. Metals, 27 (1963), 206.

28) Z. Nishiyama and K. Shimizu: Bull. Japan Inst. Metals, 2 (1963), 153.

29) C. M. Wayman : J. Iron Steel Inst. Special Rept. No. 93 (1965), 153.

30) F. Förster and E. Scheil : Z. Metallk., 32 (1940), 165.

31) T. Honma: J. Japan Inst. Metals, 21 (1957), 51, 122, 126.

32) R. P. Reed: Acta Met., 15 (1967), 1287.

33) E. E. Underwood: J. Metals, 14 (1962), 914.

34) D. Oelschlägel : Bull. Japan Inst. Metals, 6 (1967), 11.

35) D. C. Ludwigson and J. A. Berger: J. Iron Steel Inst., 207 (1969), 63.

36) W. W. Gerberich, P. L. Hemmings, and V. F. Zackay: Trans. AIME, 245 (1969), 1124.

37) S. D. Antolovich: Trans. AIME, 242 (1968), 2371. 